\title{
Corporate Social Responsibility and Firm Performance: Evidence from Pakistan
}

\author{
NAEEM KHAN \\ Ph.D. Scholar, Foundation University Rawalpindi. \\ Email: naeemkkhan87@gmail.com \\ Tel: +92302-2430216 \\ Dr. QAISAR ALI MALIK \\ Associate Professor, Head of Department, Foundation University Rawalpindi \\ Email: qamalik@gmail.com
}

\author{
AHSEN SAGHIR \\ Ph.D. Scholar, Foundation University Rawalpindi. \\ Email: ahsensaghir@gmail.com
}

Tel: $+92346-5382554$

\begin{abstract}
The current study aims at exploring the relationship of CSR practices with firm performance (FP) in the non-financial sector of the Pakistan stock exchange (PSX). For this purpose, the study uses sample data of 231 companies listed at PSX. The study uses "donation amount to sales" as a proxy variable for CSR practices and return on equity (ROE), return on assets (ROA) as the proxies of firm performance. The models are tested using a panel regression estimation technique with a fixed effect method, as suggested by Hausman test. The results show that CSR is significantly positively related to ROE. Findings indicate that investment in CSR brings positive change in a firm's profitability which ultimately leads to an increase in the shareholder's wealth.
\end{abstract}

Keywords: Corporate Social Responsibility, Pakistan Stock Exchange, Firm Performance, Fixed Effect Model, Non-financial Sector.

\section{Introduction}

Nowadays, many companies do CSR related work but unfortunately, their spending on CSR practices fail to get due recognition, this is perhaps due to their poor reporting mechanism (Mellahi \& Wood, 2003). The CSR activates, however, benefit business organizations in achieving a competitive advantage over their rivalries and bring a good reputation to them. Weber (2008) argue that CSR activities give an extra mile to organizations in maintaining a license to function, help them in reducing risks, gaining tax advantages, and providing benefits in the shape of efficiency gains. Over time, in many countries, the conduct of CSR activities has been made mandatory. Through a special clause in the Indian Companies Act 2013, business organizations that have a net worth over 5 billion are bound to perform CSR activities. The concept of CSR motivates organizations to do more economic welfare, social and environment-friendly activities which in return develops trust and maintains consumer confidence. Eventually, these activities shape the future of the county's economy (D'amato, Henderson, \& Florence, 2009). 
The CSR and its linkages are mostly investigated in the developed part of the world (Bagh, Khan, Azad, Saddique, \& Khan, 2017). The statistical association between corporate social responsibility with firm profitability is relatively less explored in developing nations (Pradhan \& Nibedita, 2019). Literature reports inconclusive, contradictory findings for emerging and developing countries (Ali, Danish, \& Asrar-ul-Haq, 2020; Blasi, Caporin, \& Fontini, 2018; Nkemjika \& Nkechi, 2017; Riyadh, Sukoharsono, \& Alfaiza, 2019; Scholtens, 2008; Wulfson, 2001; Yunis, Durrani, \& Khan, 2017).

The practices of CSR currently prevailing in the developed part of the world are significantly different from the rest of the world (emerging \& developing economies). The CSR practices laid out by the governments of developing nations are rarely followed. Business entities face economic challenges while doing CSR work both at the local and international levels (Bagh et al., 2017). These challenges include issues of bad governance, natural disasters, weak \& corrupt policies of institutions, and poor control of internal admin. Under these conditions, it becomes extremely difficult to carry out CSR work (Jamali \& Mirshak, 2007; Javeed \& Lefen, 2019; Khan \& Lund-Thomsen, 2011). However, there are many Pakistani companies that carryout various social, philanthropic, environmental, and other CSR work.

The linkage of CSR and FP is well explored in literature. However, literature reports mix, the inconclusive relationship between CSR and FP, this relationship needs further investigation (Blasi et al., 2018). Literature is evident that most of the work on the said relationship is conducted in the developed part of the world (Bagh et al., 2017). There exists limited work on developing countries on the association of CSR and FP (Cherian et al., 2019). Owing to the less or partial work on the CSR with inclusive findings in Pakistan. The current study aims at the exploration of the association between CSR practices and financial performance by taking the data of non-financial sector companies listed Pakistan stock exchange (PSX).

The possible reasons for contradictory findings on the relation of CSR with firm profitability are may be due to less number of companies considered for data analysis with smaller data sets and due to the survey based on single sector companies (Kakakhel, Ilyas, Iqbal, \& Afeef, 2015; Kiran, 2015; Malik \& Nadeem, 2014). To the best of the author's knowledge, it is the first study providing evidence on the effect of CSR on firm performance in developing region, bridging the research gap by taking into account the entire nonfinancial sector companies of PSX, with a larger data sets spanning over 12 years from 2005 to 2017 and with data of 231 sample companies.

The remainder of this study is organized in the following sequence. The related review of literature is presented in the second section, research methodology, results, and conclusion are described in section $3^{\text {rd }}$, $4^{\text {th, }}$ and $5^{\text {th }}$ sections respectively.

\section{Literature Review}

The concept of CSR, perhaps the first time was given by Shelton in 1923 (Feng, Chen, \& Tang, 2018). He argued that protecting the interest of society is also the responsibility of an enterprise while just focusing on the increase of its profits (Bichta, 2003). The uprising phase of CSR started in 1950 when Bowen defined CSR as an obligation of businessmen to follow, an obligation toward the society. The concept of CSR further progressed in 1960, when the movement of customer's rights, women's rights, and environment protection was started (M. Yang, Bento, \& Akbar, 2019). Frederick (1960) argues that it is also the responsibility of a firm to care about the socio-economic welfare of society and do whatever necessary to satisfy the expectations of society. Davis (2014) elaborates the concept of CSR a bit further, by suggesting that CSR is surely a 'right thing' for firms to do. In 1970, the scope of CSR got new wheels when Johnson (1973) proposed the detailed dimensions of CSR, which consists of employees, suppliers, government, and the local community. A well-known definition of CSR was proposed by Carroll (1991). Carroll (1991) defines that CSR is the sum of obligations that society expects from firms, and argued that firms must be willing to fulfill these expectations. Carroll divides CSR into four dimensions, these dimensions are economic, legal, ethical, and discretionary. 
Researchers own diverse opinions on the relationship between CSR and the performance of companies (Alamgir \& Nasir Uddin, 2017). Bagh et al. (2017) show a significant positive link of CSR with firm performance. Verma (2011) reports that engagement in CSR enhances firm performance.

Investments made in various social activities, charitable works, staff welfare programs, and protection of the environment, ultimately improve the reputation of firms (McGuire, Sundgren, \& Schneeweis, 1988). An efficient firm can improve its reputation in the market by investing in CSR activities (Simpson \& Kohers, 2002). Investments in CSR practices give a boost to the goodwill and reputation of companies which leads to an increase in the profitability of firms (Barrett, Corbet, \& Larkin, 2019; Bauer, Koedijk, \& Otten, 2005). Consequently, an increase in financial performance motivates firm managers to engage more and more in CSR programs, it shows that CSR affects firm performance.

A panel of the researchers also believes that spending on CSR activities unnecessarily increases the cost and does not yield any direct benefit to firms (Aupperle, Carroll, \& Hatfield, 1985; Friedman, 2007). A recent study on the relation of CSR and FP shows a negative effect of CSR on firm performance (Lin, Law, Ho, \& Sambasivan, 2019). A. S. Yang and Baasandorj (2017) also report a negative association between the relationship of CSR and firm performance. Preston and O'bannon (1997) argue CSR spending affects financial performance negatively. Looking from the perspective of agency theory the investment made in CSR be in a way that maximizes the wealth of shareholders.

The decisions made by managers must be in the interest of shareholders and managers should avoid all those activities which do not maximize shareholders' profit (Bauer et al., 2005). In this regard decisions related to social activities may create a conflict of interest between management and shareholders that can lead to agency cost and affect firm financial performance negatively (Preston \& O'bannon, 1997). Investment in CSR for the manager's gain is certainly not in the interest of shareholders (Brammer \& Millington, 2008). The stakeholder theory, however, suggests maintaining good relations with all direct and indirect stakeholders of the company (Freeman, 1984). Business organizations can have good relations with all stakeholders when they get to engage in CRS practices (Gangi, Meles, Monferrà, \& Mustilli, 2018).

The importance of CSR activities and their communication to stakeholders are not appreciated in emerging economies (Lenssen, Perrini, Tencati, Lacy, \& Foo, 2007). While in developing economies, CSR activities performed by companies are not well communicated to stakeholders probably due to their poor reporting which somehow negatively affects the performance of the firm (Mellahi \& Wood, 2003). Wood (1991) explore additional linkages of CSR on firm performance with the mediating role of investment inefficiency. By applying the fixed effect model, his study finds that investment inefficiency fully mediates the link between CSR and firm performance.

\section{Research Methodology}

\section{Data Description and Population}

In order to check the relationship of CSR practices on firms' profitability, the study uses data based on equity prices of Pakistani companies. The frequency of data is based on annual values. The population of the study consists of all companies listed at the Pakistan stock exchange (PSX) at the time of data retrieval.

\section{Sample and Sampling Technique}

The sample of the study consists of all non-financial sector companies listed at the Pakistan stock exchange. All financial sector companies are excluded as these companies have different reporting structures. The random sampling technique is implied in the study for data collection. 


\section{Data Collection and Time Frame}

The data of 231 non-financial companies is collected from the published financial reports. The study uses relatively a larger data set of 12 years, ranging from 2005 to 2017.

\section{Variables of the Study}

Corporate social responsibility (CSR) is the dependent variable of the study while firm performance (FP) is the independent variable. For analysis, the study uses proxies as suggested by the literature. The CSR variable is estimated using the ratio of 'donation amount to sales' which is in line with the CSR proxy taken by Niu, Xiaoyan, and Pei (2020). To estimate a firm performance study uses two proxies; return on assets (ROA) and return of equity (ROE). ROA and ROE are the most commonly used proxies for the measurement of firm performance (Lee \& Huang, 2020). The control variables of the study include size, leverage, and age which are also in line with (A. S. Yang \& Baasandorj, 2017). For analysis fixed effect model of panel data is used.

Table 1: Measurement of Variables

\begin{tabular}{|lll|}
\hline Variable & Proxy & Reference \\
\hline Independent Variable & The ratio of donation amount/sales & Niu et al. (2020) \\
Dependent Variable & & \\
Firm Performance & ROA= Net profit after tax/ total assets & Malik and Nadeem \\
& ROE = Net profit after tax/ shareholder equity & $(2014)$ \\
Control Variables & Log of total assets & \\
Size & Age of the firm in years & A. S. Yang and \\
Age & Total liabilities/ Total assets & Baasandorj (2017) \\
Leverage & & \\
\hline
\end{tabular}

To probe the impact of CSR on FP following econometric models are used:

$$
\begin{aligned}
& \mathrm{ROA}_{i, t}=\beta_{0}+\beta_{1} \mathrm{CSR}_{i, t}+\beta_{2} \mathrm{SIZE}_{i, t}+\beta_{3} A G E_{i, t}+\beta_{4} L E V E R A G E_{i, t}+\varepsilon_{i, t} \text {------------------(Model-1) } \\
& \mathrm{ROE}_{i, t}=\beta_{0}+\beta_{1} \mathrm{CSR}_{i, t}+\beta_{2} \mathrm{SIZE}_{i, t}+\beta_{3} A G E_{i, t}+\beta_{4} L E V E R A G E_{i, t}+\varepsilon_{i, t}
\end{aligned}
$$

Where, $R O A_{i, t}$ and $R O E_{i, t}$ represents the firm performance of "firm $i$ " at "time $t$ ". CSR $R_{i, t}$ signifies $C S R$ which is measured through 'ratio of donation amount to sales' of "firm $i$ " at "time $t$ ". While $S I Z E_{i, t}, A G E_{i, t}$, LEVERAGE $E_{i, t}$ represent control variables of the study of "firm $i$ " at "time $t$ ".

\section{Results and Discussions}

\section{Descriptive Statistics}

Table 2 exhibits the results of descriptive statistics. The descriptive statistics are calculated to get a general feel of data, which shows the values of dependent, independent, and control variables. The Mean values of CSR, ROA, ROE are 0.0016, 0.0564, and 0.0794 respectively. The statistics of standard deviation for CSR, ROA, ROE are $0.0079,0.0873$, and 0.5843 respectively. Descriptive statistics confirm that all these values are under acceptable ranges and no data discrepancy is observed which validates this data for further analysis. 
Table 2: Descriptive Statistics

\begin{tabular}{|llrrlll|}
\hline & CSR & ROA & \multicolumn{1}{c}{ ROE } & SIZE & AGE & LEV \\
\hline Mean & 0.0016 & 0.0564 & 0.0794 & 15.4813 & 3.5072 & 0.5554 \\
Median & 0.0003 & 0.0467 & 0.1139 & 15.3378 & 3.5263 & 0.5670 \\
Max & 0.2099 & 0.3566 & 1.9018 & 20.2566 & 5.0562 & 1.9640 \\
Min & 0.0001 & -0.2850 & -13.232 & 11.2784 & 1.3862 & 0.0288 \\
S.D & 0.0079 & 0.0873 & 0.5843 & 1.4753 & 0.4987 & 0.2274 \\
\hline
\end{tabular}

\section{Correlations Analysis}

Table 3 reports the results of correlation statistics for variables used in the study. The correlation analysis is conducted as a diagnostic test for further analysis. This correlation analysis guides on the relationship of variables, either positive or negative, and as-well-as on their directions. Consistent with a stream of literature, the correlation matrix shows there exists a negative correlation between CSR and proxies of firm performance i.e ROA and ROE. Prior studies argue that business entities must concentrate on the fulfillment of economic and legal responsibilities considering it as their foremost obligation (Cho, Chung, \& Young, 2019). It describes that an investment in CSR practices leads to having a negative influence on the performance of the firm. However, the values of ROA (-0.0526) and ROE (-0.0484) concerning CSR further reveal that there exists a weak negative correlation as evident from table 3 . The prime focus of firms should be on the fulfillment of fundamental and final objective that is the maximization of shareholders' profit. The CSR practices aiming at other objectives over economic and legal responsibilities can affect the maximization of shareholders' profit negatively (McWilliams \& Siegel, 2001). Since correlation analysis is a relatively poor measure of association. The casual nexus among variables is further investigated using regression analysis.

\begin{tabular}{|c|c|c|c|c|c|c|}
\hline 969 & CSR & ROA & ROE & SIZE & AGE & LEV \\
\hline CSR & 1 & & & & & \\
\hline ROA & -0.052 & 1 & & & & \\
\hline ROE & -0.048 & 0.400 & 1 & & & \\
\hline SIZE & -0.064 & 0.173 & 0.118 & 1 & & \\
\hline AGE & 0.027 & 0.016 & -0.025 & 0.142 & 1 & \\
\hline LEV & 0.063 & -0.549 & -0.158 & -0.025 & -0.103 & 1 \\
\hline
\end{tabular}

\section{Regression Analysis}

The results for regression analysis are reported in Table 4. The models are analyzed using panel regression estimation with a fixed effect method as suggested by Hausman fixed test. The results of the probability of F statistics for Model-1 \& Model-2 are under acceptable bond ( $\mathrm{F}>0.05)$, which indicates hypothesized models are structurally fit, which means models fit the data.

The results of regression model-1, show an insignificant impact of CSR practices on the proxy (ROA) of firm performance as coefficient value is (0.0617) and the p-value is (0.7623), results are consistent with the finding of earlier work of (Kiran, 2015; Szegedi, Khan, \& Lentner, 2020). It shows that CSR practices are not a leading predictor proxy in comparison to the control variable i.e LEV as coefficient value is $(-0.2227)$ and the $\mathrm{p}$-value is $(0.0000)$ of this study.

However, the result of regression model-2 shows a significant impact of CSR practices on the firm performance (ROE) as coefficient value is (7.3038) and the p-value is (0.0004). The coefficient sign is positive which shows, in line with prior literature, it shows CSR activity carried by business entities will bring positive change in firms' profitability (measured through ROE). The investment made by companies in CSR work brings positive outcomes in the shape of increased firm profitability (M. Yang et al., 2019). 
The control variables i.e SIZE coefficient value (0.04329), p-value is (0.2504) and for AGE coefficient value (-0.2053), $\mathrm{p}$-value is (0.1063) are insignificant. The remaining control variable i.e LEV significant as shows by $\mathrm{p}$-value is $(0.0000)$, the coefficient sign is negative $(-0.847334)$. The results of $\mathrm{R}^{2}$ for Model-2 show a $22.57 \%$ variation in $\mathrm{ROE}$ is explained by the independent variables.

Table 4: Regression Analysis

\begin{tabular}{|lllllll|}
\hline & ROA & \multicolumn{5}{l|}{ ROE } \\
\hline Measures & Coeff. & t-Stats & Prob. & Coeff. & t-Stats & Prob. \\
CSR & 0.0617 & 0.30252 & 0.7623 & 7.3038 & 3.5281 & 0.0004 \\
AGE & -0.0228 & -1.8248 & 0.0682 & -0.2053 & -1.6160 & 0.1063 \\
LEV & -0.2227 & -21.117 & 0.0000 & -0.8473 & -7.8495 & 0.0000 \\
SIZE & -0.0062 & -1.6712 & 0.0949 & 0.0432 & 1.1497 & 0.2504 \\
R2 & 0.6597 & & & 0.2257 & & \\
Adjusted R2 & 0.6162 & & & 0.1263 & & \\
F-stats & 15.162 & & & 2.2722 & & \\
Prob. (F-stats) & 0.0000 & & & 0.0000 & & \\
\hline
\end{tabular}

\section{Conclusion}

In this study, the association between CSR practices and firm performance is examined for companies listed in Pakistan, with an aim to extend the existing body of knowledge specifically in a developing region. A major chunk of prior work has focused on developed counties while findings are inconclusive in developing economies (Blasi et al., 2018). The result of regression analysis shows CSR practices significantly positively affect performance indicators (ROE). It indicates that any investment made into CSR projects will ultimately result in the increase of shareholders' wealth. The results of the study are consistent with many previous studies. Many companies do not participate actively in CSR-related actives with fear that such practices may not enhance shareholders' wealth or perform better in the stock market (M. Yang et al., 2019). However, results show that CSR investment is linked positively to their output in terms of their performance (firms' profitability). CSR practices help to maintain a strong relationship with shareholders as these activates create a positive perception of companies' main operations that improves customer loyalty and brand image in the market. Ultimately, it increases market share and firms' revenue that leads to increase in firms' performance.

The study is important as it enhances understanding of the association of CSR practices and firm performance. It testifies CSR practices are in the favor of shareholders through an investigation based on a larger data set from a perspective of a developing country. The empirical finding of the study suggests that investment in CSR activities boosts a firm's profitability which in return maximizes the wealth of shareholders.

In light of the findings, this study has the following practical implications. First, companies must upgrade their reporting standard so that their CSR work may get due recognition in the market. And second, the fact of a positive association between CSR practices and firms' performance motivates companies to include CSR activates in their core business plan as it helps corporations to enhance shareholders' value.

Future research may investigate the effect of CSR on firm performance by adding the mediating variable of research and development (R\&D). The R\&D outflows (expenditure) bring innovation which boosts the wealth of shareholders as-well-as provides innovative products and services to the public at large. 


\section{References}

Alamgir, M., \& Nasir Uddin, M. (2017). The mediating role of corporate image on the relationship between corporate social responsibility and firm performance: An empirical study. International Journal of Business and Development Studies, 9(1), 91-111.

Ali, H. Y., Danish, R. Q., \& Asrar-ul-Haq, M. (2020). How corporate social responsibility boosts firm financial performance: The mediating role of corporate image and customer satisfaction. Corporate Social Responsibility and Environmental Management, 27(1), 166-177.

Aupperle, K. E., Carroll, A. B., \& Hatfield, J. D. (1985). An empirical examination of the relationship between corporate social responsibility and profitability. Academy of management journal, 28(2), 446463.

Bagh, T., Khan, M. A., Azad, T., Saddique, S., \& Khan, M. A. (2017). The Corporate Social Responsibility and Firms' Financial Performance: Evidence from Financial Sector of Pakistan. International Journal of Economics and Financial Issues, 7(2), 301-308.

Barrett, S., Corbet, S., \& Larkin, C. (2019). Sustainability, accountability and democracy: Ireland's Troika experience. Finance Research Letters, 28, 53-60.

Bauer, R., Koedijk, K., \& Otten, R. (2005). International evidence on ethical mutual fund performance and investment style. Journal of Banking \& Finance, 29(7), 1751-1767.

Bichta, C. (2003). Corporate socially responsible (CSR) practices in the context of Greek industry. Corporate Social Responsibility and Environmental Management, 10(1), 12-24.

Blasi, S., Caporin, M., \& Fontini, F. (2018). A multidimensional analysis of the relationship between corporate social responsibility and firms' economic performance. Ecological Economics, 147, 218-229.

Brammer, S., \& Millington, A. (2008). Does it pay to be different? An analysis of the relationship between corporate social and financial performance. Strategic Management Journal, 29(12), 1325-1343.

Carroll, A. B. (1991). The pyramid of corporate social responsibility: Toward the moral management of organizational stakeholders. Business horizons, 34(4), 39-48.

Cherian, J., Umar, M., Thu, P. A., Nguyen-Trang, T., Sial, M. S., \& Khuong, N. V. (2019). Does Corporate Social Responsibility Affect the Financial Performance of the Manufacturing Sector? Evidence from an Emerging Economy. Sustainability, 11(4), 1182.

Cho, S. J., Chung, C. Y., \& Young, J. (2019). Study on the Relationship between CSR and Financial Performance. Sustainability, 11(2), 343.

D'amato, A., Henderson, S., \& Florence, S. (2009). Corporate social responsibility and sustainable business. A Guide to Leadership tasks and functions, 102.

Davis, K. (2014). Can business afford to ignore its social responsibility. California Management Review, 70-76.

Feng, Y., Chen, H., \& Tang, J. (2018). The impacts of social responsibility and ownership structure on sustainable financial development of China's energy industry. Sustainability, 10(2), 301.

Frederick, W. C. (1960). The growing concern over business responsibility. California Management Review, 2(4), 54-61.

Freeman, R. (1984). 1984, Strategic Management: A stakeholder approach. Boston: Pitman.

Friedman, M. (2007). The social responsibility of business is to increase its profits Corporate ethics and corporate governance (pp. 173-178): Springer.

Gangi, F., Meles, A., Monferrà, S., \& Mustilli, M. (2018). Does corporate social responsibility help the survivorship of SMEs and large firms? Global Finance Journal, 100402.

Jamali, D., \& Mirshak, R. (2007). Corporate social responsibility (CSR): Theory and practice in a developing country context. Journal of Business Ethics, 72(3), 243-262.

Javeed, S., \& Lefen, L. (2019). An analysis of corporate social responsibility and firm performance with moderating effects of CEO power and ownership structure: A case study of the manufacturing sector of Pakistan. Sustainability, 11(1), 248.

Johnson, H. L. (1973). A Berkeley View of Business and Society: A Review of The Corporate Dilemma: Traditional Values versus Contemporary Problems by S. Prakash Sethi and Dow Votaw (Prentice-Hall, 1973). California Management Review, 16(2), 95-100. 
Kakakhel, S. J., Ilyas, M., Iqbal, J., \& Afeef, M. (2015). Impact of Corporate Social Responsibility on Financial Performance: Evidence from Pakistan's Cement Industry. Abasyn University Journal of Social Sciences, 8(2).

Khan, F. R., \& Lund-Thomsen, P. (2011). CSR as imperialism: Towards a phenomenological approach to CSR in the developing world. Journal of Change Management, 11(1), 73-90.

Kiran, S. (2015). Corporate social responsibility and firm profitability: A case of oil and gas sector of Pakistan. City University Research Journal, 5(1).

Lee, M., \& Huang, Y.-L. (2020). Corporate Social Responsibility and Corporate Performance: A Hybrid Text Mining Algorithm. Sustainability, 12(8), 3075.

Lenssen, G., Perrini, F., Tencati, A., Lacy, P., \& Foo, L. M. (2007). Stakeholder engagement in emerging economies: considering the strategic benefits of stakeholder management in a cross-cultural and geopolitical context. Corporate Governance: The international journal of business in society.

Lin, W. L., Law, S. H., Ho, J. A., \& Sambasivan, M. (2019). The causality direction of the corporate social responsibility-Corporate financial performance Nexus: Application of Panel Vector Autoregression approach. The North American Journal of Economics and Finance, 48, 401-418.

Malik, M. S., \& Nadeem, M. (2014). Impact of corporate social responsibility on the financial performance of banks in Pakistan. International Letters of Social and Humanistic Sciences, 10(1), 9-19.

McGuire, J. B., Sundgren, A., \& Schneeweis, T. (1988). Corporate social responsibility and firm financial performance. Academy of management journal, 31(4), 854-872.

McWilliams, A., \& Siegel, D. (2001). Corporate social responsibility: A theory of the firm perspective. Academy of management review, 26(1), 117-127.

Mellahi, K., \& Wood, G. (2003). The role and potential of stakeholders in "hollow participation": Conventional stakeholder theory and institutionalist alternatives. Business and Society Review, 108(2), 183-202.

Niu, Z., Xiaoyan, Z., \& Pei, H. (2020). Effect of Perceived Status of Entrepreneur on Firm's CSR Behaviour: Evidence from Chinese Private Enterprises Survey. Finance Research Letters, 101561.

Nkemjika, O. M., \& Nkechi, O. (2017). Corporate Social Responsibilities and Firm Performance: A Comparative study of Banking and Non-Bank Sector in Nigeria. Int. J. Manag. Excell, 8, 946-955.

Pradhan, A. K., \& Nibedita, B. (2019). The determinants of corporate social responsibility: Evidence from Indian Firms. Global Business Review, 0972150918814318.

Preston, L. E., \& O'bannon, D. P. (1997). The corporate social-financial performance relationship: A typology and analysis. Business \& society, 36(4), 419-429.

Riyadh, H. A., Sukoharsono, E. G., \& Alfaiza, S. A. (2019). The impact of corporate social responsibility disclosure and board characteristics on corporate performance. Cogent Business \& Management, 6(1), 1647917.

Scholtens, B. (2008). A note on the interaction between corporate social responsibility and financial performance. Ecological Economics, 68(1-2), 46-55.

Simpson, W. G., \& Kohers, T. (2002). The link between corporate social and financial performance: Evidence from the banking industry. Journal of Business Ethics, 35(2), 97-109.

Szegedi, K., Khan, Y., \& Lentner, C. (2020). Corporate Social Responsibility and Financial Performance: Evidence from Pakistani Listed Banks. Sustainability, 12(10), 4080.

Verma, S. (2011). Why Indian companies indulge in CSR? Journal of Management and Public Policy, 2(2), 52-69.

Weber, M. (2008). The business case for corporate social responsibility: A company-level measurement approach for CSR. European Management Journal, 26(4), 247-261.

Wood, D. J. (1991). Corporate social performance revisited. Academy of management review, 16(4), 691718.

Wulfson, M. (2001). The ethics of corporate social responsibility and philanthropic venturesl. Journal of Business Ethics, 29(1-2), 135-145.

Yang, A. S., \& Baasandorj, S. (2017). Exploring CSR and financial performance of full-service and lowcost air carriers. Finance Research Letters, 23, 291-299. 
Yang, M., Bento, P., \& Akbar, A. (2019). Does CSR Influence firm performance indicators? evidence from Chinese pharmaceutical enterprises. Sustainability, 11(20), 5656.

Yunis, M. S., Durrani, L., \& Khan, A. (2017). Corporate social responsibility (CSR) in Pakistan: A critique of the literature and future research agenda. Business \& Economic Review, 9(1), 65-88. 